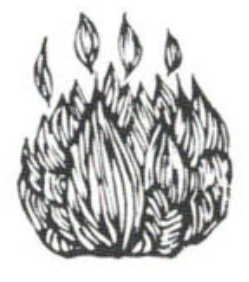

The Victims of Democracy 



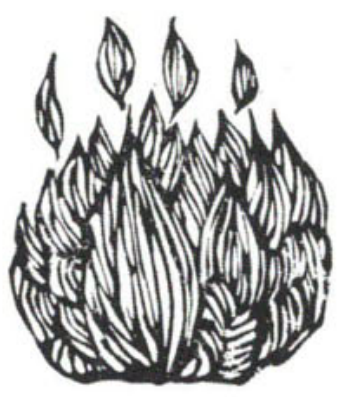

\section{The Victims of Democracy}

Malcolm X and the Black Revolution

by Eugene Victor Wolfenstein

University of California Press

Berkeley Los Angeles London 
University of California Press

Berkeley and Los Angeles, California

University of California Press, Ltd.

London, England

(C) 1981 The Regents of the University of California

Printed in the United States of America

123456789

Library of Congress Cataloging in Publication Data

Wolfenstein, Eugene Victor.

The victims of democracy: Malcolm X and the black revolution.

Bibliography: p.

Includes index

I. Little, Malcolm, 1925-1965. 2. Black Muslims-Biography. 3. AfroAmericans-Biography. 4. Afro-Americans-Race identity. I. Title.

BP223.281579 361.2'092'4[B] 79-6355I

ISBN 0-520-03903-3 